Prepared in cooperation with the U.S. Fish and Wildlife Service

Rock Gnome Lichen (Gymnoderma lineare) Monitoring

Assessment, Southern Appalachian Mountains, 1983-2008

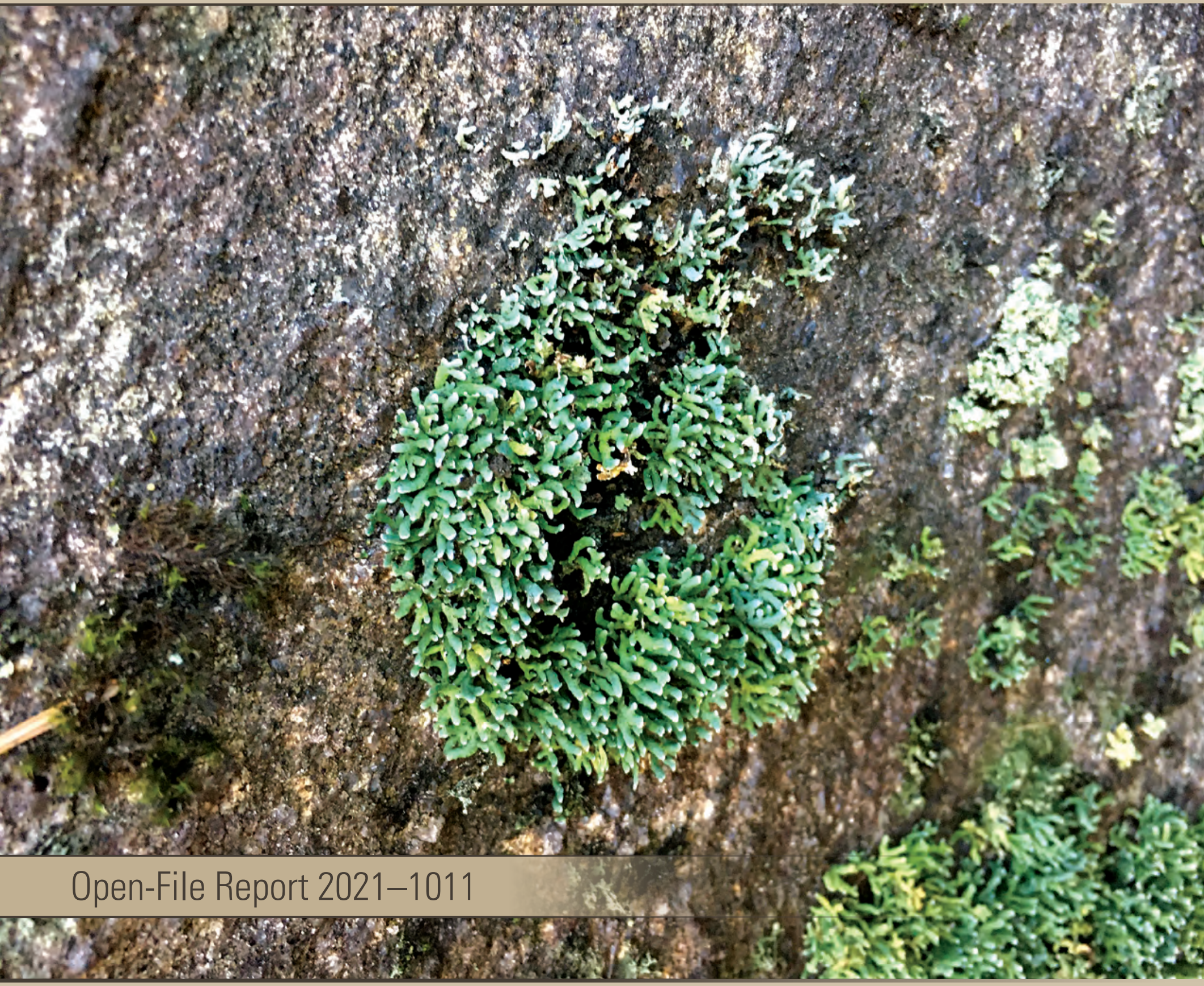

U.S. Department of the Interior

U.S. Geological Survey 
Cover: Rock gnome lichen (Gymnoderma lineare), Roan Mountain, North Carolina. Photograph by Andrea Woodward, U.S. Geological Survey, November 2019. 


\section{Rock Gnome Lichen (Gymnoderma lineare) Monitoring Assessment, Southern Appalachian Mountains, 1983-2008}

By Andrea Woodward

Prepared in cooperation with the U.S. Fish and Wildlife Service

Open-File Report 2021-1011 


\section{U.S. Geological Survey, Reston, Virginia: 2021}

For more information on the USGS - the Federal source for science about the Earth, its natural and living resources, natural hazards, and the environment—visit https://www.usgs.gov or call 1-888-ASK-USGS.

For an overview of USGS information products, including maps, imagery, and publications, visit https://store.usgs.gov/.

The findings and conclusions in this report are those of the author and do not necessarily represent the views of the U.S. Fish and Wildlife Service.

Any use of trade, firm, or product names is for descriptive purposes only and does not imply endorsement by the U.S. Government.

Although this information product, for the most part, is in the public domain, it also may contain copyrighted materials as noted in the text. Permission to reproduce copyrighted items must be secured from the copyright owner.

Suggested citation:

Woodward, A., 2021, Rock gnome lichen (Gymnoderma lineare) monitoring assessment, southern Appalachian Mountains, 1983-2008: U.S. Geological Survey Open-File Report 2021-1011, 12 p., https://doi.org/10.3133/ ofr20211011.

ISSN 2331-1258 (online) 


\section{Contents}

Abstract

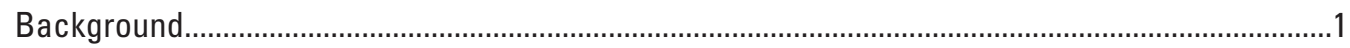

Current and Historical Distribution .......................................................................................

Threats and Limiting Factors .............................................................................................

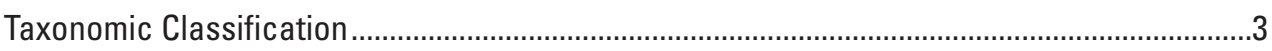

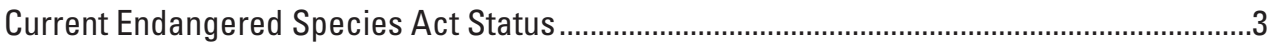

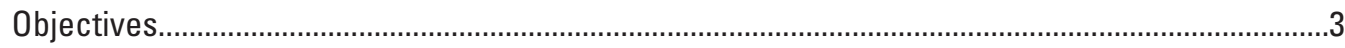

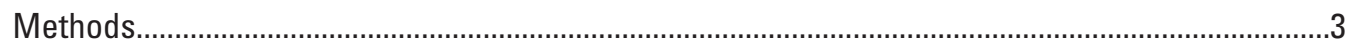

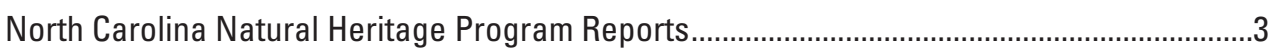

Rapid Assessment Protocol ..............................................................................................

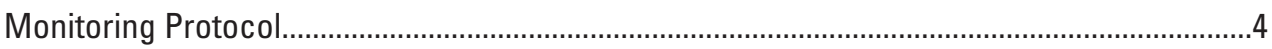

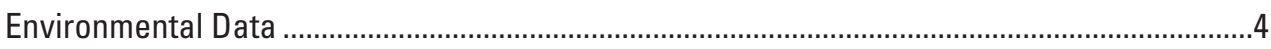

Results of Updated Analysis of Rock Gnome Populations..........................................................

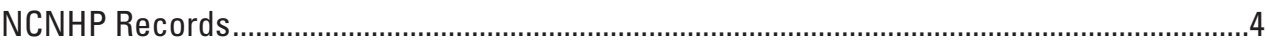

Rapid Assessment Protocol ...............................................................................................

Monitoring Protocol.............................................................................................................

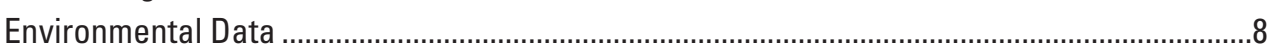

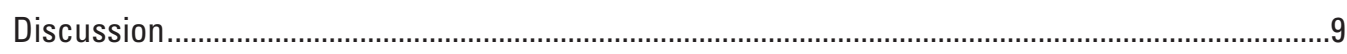

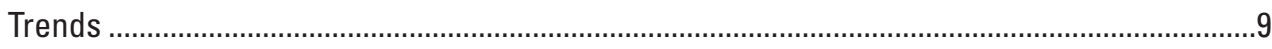

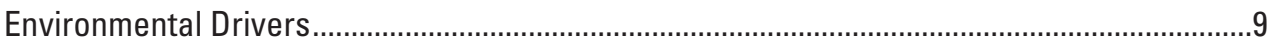

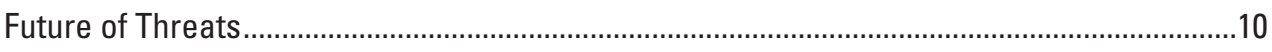

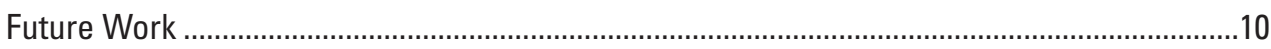

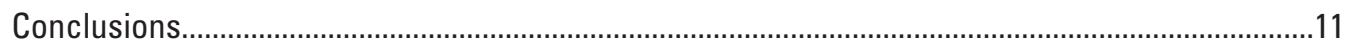

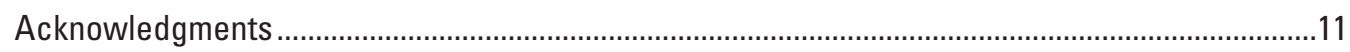

References Cited

\section{Figures}

1. Image showing distribution of known populations of Gymnoderma lineare and monitoring sites, southern Appalachian Mountains.

2. Graphs showing trends in annual weather variables of air temperature and precipitation (North Carolina Division 1), acid (hydrogen ion) total nitrogen and sulfate deposition (National Atmospheric Deposition Program site at Mount Mitchell, North Carolina), and peak flow and annual average discharge (U.S. Geological Survey streamgage 03161000, South Fork New River near Jefferson, North Carolina).

3. Graph showing trends in cover of rock gnome lichen (Gymnoderma lineare) determined over several monitoring time intervals, southern Appalachian Mountains 


\section{Tables}

1. Rock gnome lichen (Gymnoderma lineare) monitoring sites with quantitative evidence of change found in North Carolina Natural Heritage Program records, southern Appalachian Mountains, 1987-2008

2. Rock gnome lichen (Gymnoderma lineare) sites with rapid assessment protocol data collected in North Carolina in 2008

3. Cover of rock gnome lichen (Gymnodermna lineare) at monitoring sites with repeated estimates, southern Appalachian Mountains, 1995-2008

4. Summary of monitoring results by time interval for rock gnome lichen (Gymnoderma lineare), southern Appalachian Mountains, 1995-2008.

\section{Conversion Factors}

International System of Units to U.S. customary units

\begin{tabular}{lcl}
\hline \multicolumn{1}{c}{ Multiply } & By & \multicolumn{1}{c}{ To obtain } \\
\hline meter $(\mathrm{m})$ & 3.281 & foot $(\mathrm{ft})$ \\
meter $(\mathrm{m})$ & 1.094 & yard $(\mathrm{yd})$ \\
kilometer $(\mathrm{km})$ & 0.6214 & mile $(\mathrm{mi})$ \\
\hline & Area & \\
\hline square kilometer $\left(\mathrm{km}^{2}\right)$ & 247.1 & acre \\
square centimeter $\left(\mathrm{cm}^{2}\right)$ & 0.001076 & square foot $\left(\mathrm{ft}^{2}\right)$ \\
square meter $\left(\mathrm{m}^{2}\right)$ & 10.76 & square foot $\left(\mathrm{ft}^{2}\right)$ \\
hectare $($ ha) & 0.003861 & square mile $\left(\mathrm{mi}^{2}\right)$ \\
square kilometer $\left(\mathrm{km}^{2}\right)$ & 0.3861 & square mile $\left(\mathrm{mi}^{2}\right)$ \\
\hline & Application rate & \\
\hline kilogram per hectare per year $([\mathrm{kg} / \mathrm{ha}] / \mathrm{yr})$ & 0.8921 & pound per acre per year $([\mathrm{lb} / \mathrm{acre}] / \mathrm{yr})$ \\
\hline
\end{tabular}

Temperature in degrees Celsius $\left({ }^{\circ} \mathrm{C}\right)$ may be converted to degrees Fahrenheit $\left({ }^{\circ} \mathrm{F}\right)$ as follows:

$$
{ }^{\circ} \mathrm{F}=\left(1.8 \times{ }^{\circ} \mathrm{C}\right)+32 .
$$

\section{Datums}

Vertical coordinate information is referenced to the North American Vertical Datum of 1988 (NAVD 88).

Horizontal coordinate information is referenced to the North American Datum of 1983 (NAD 83).

Elevation, as used in this report, refers to distance above the vertical datum. 


\section{Abbreviations}

EO element occurrence

NCNHP North Carolina Natural Heritage Program

FWS U.S. Forest and Wildlife Service

NADP National Atmospheric Deposition Program

USGS U.S. Geological Survey 



\title{
Rock Gnome Lichen (Gymnoderma lineare) Monitoring Assessment, Southern Appalachian Mountains, 1983-2008
}

\author{
By Andrea Woodward
}

\section{Abstract}

Rock gnome lichen (Gymnoderma lineare [Evans] Yoshimura and Sharp) was listed as a federally endangered species in 1995. It is endemic to the southern Appalachian Mountains, with most known populations occurring in North Carolina, where it grows on vertical rock faces in the fog zone above an elevation of 1,525 meters or in humid, deep river gorges. Threats to the species include recreational use of habitat by hikers, climbers and sightseers; collectors; changes in microclimate due to loss of Fraser fir (Abies fraseri) to the exotic pest balsam woolly adelgid (Adelges piceae); air pollution; and climate change. Quantified estimates of population size are limited in number and only are available from 1983 to 2008. They show that known rock gnome populations increased in number during this period and increased in size from 1996 to 2008. The period of increase coincided with negative trends in nitrogen and sulfur deposition, stable precipitation and streamflow, and a positive trend in air temperature. Populations may have been afforded greater protection from recreational activities and collectors during this time. Specific incidents of population decline were associated with a high streamflow event and loss of shade owing to a fallen Fraser fir. Although the outlook for rock gnome lichen seems to have improved through 2008, threats from climate change and increasing human activity likely are increasing.

\section{Background}

\section{Current and Historical Distribution}

Rock gnome lichen (Gymnoderma lineare) is a federally listed endangered species endemic to the southern Appalachian Mountains of North Carolina, South Carolina, Tennessee, and Georgia (fig. 1). This area is a biodiversity hotspot (Estill and Cruzen, 2001), possibly because it includes boreal microhabitats that are refugia for residual species from Pleistocene flora (Loehle, 2007; Russell and others, 2009). Rock gnome lichen only occurs in areas of high humidity and primarily occurs at high elevations where fog is prevalent, or less commonly near water in deep gorges at lower elevations. At high elevations, it typically grows on vertical rock faces where periodic seepage keeps it moist. It requires filtered light but cannot tolerate high-intensity solar radiation. Consequently, it occurs on moist, generally open sites with northern exposures and with partial canopy cover on southern or western aspects mostly above an elevation of 1,525 meters (U.S. Fish and Wildlife Service [FWS], 1997). Coniferous forests near these highelevation rocky outcrops are dominated by red spruce (Picea rubens), Fraser fir with deciduous species such as sugar maple (Acer saccharum), yellow birch (Betula alleghaniensis) mountain maple (Acer spicatum), mountain ash (Sorbus americana) and American beech (Fagus grandifolia).

At the time of listing in 1995, only 32 populations of rock gnome lichen were known and 5 populations were thought to be extirpated (FWS, 1997). The first 5-year review (FWS, 2013), stated that 85 populations were known, including two populations that were thought to be extirpated in 1997. These populations were distributed across North Carolina (75), Tennessee (7), Georgia (1), South Carolina (1), and Virginia (1). Most populations covered areas less than $1 \mathrm{~m}^{2}$ and occurred on lands owned by the following parties affording with some protection for the species and its habitat: National Park Service (NPS) and U. S. Forest Service (56), State natural resource agencies (9), and one spanned property owned by the U.S. Forest Service and North Carolina State Parks. Nine populations were on privately owned land and subject to conservation agreements. Eleven populations were in private ownership and did not have any form of resource protection (FWS, 2013). Subsequent to 1995, not all 75 populations in North Carolina could be validated. See section, "Results of Updated Analysis of Rock Gnome Populations" for an updated analysis of the number and distribution of populations.

\section{Threats and Limiting Factors}

Rock gnome lichen is rare and imperiled because of its specialized habitat requirements for bare rock faces with a precise amount of moisture and light (FWS, 1997). This specialized environment may be dependent on shade and humidity from the adjacent spruce-fir forests. These forests have had substantial declines owing partly to airborne pollution and the effects of an exotic insect, the balsam woolly adelgid (Adelges piceae) on Fraser fir. Although the effects of this forest decline 


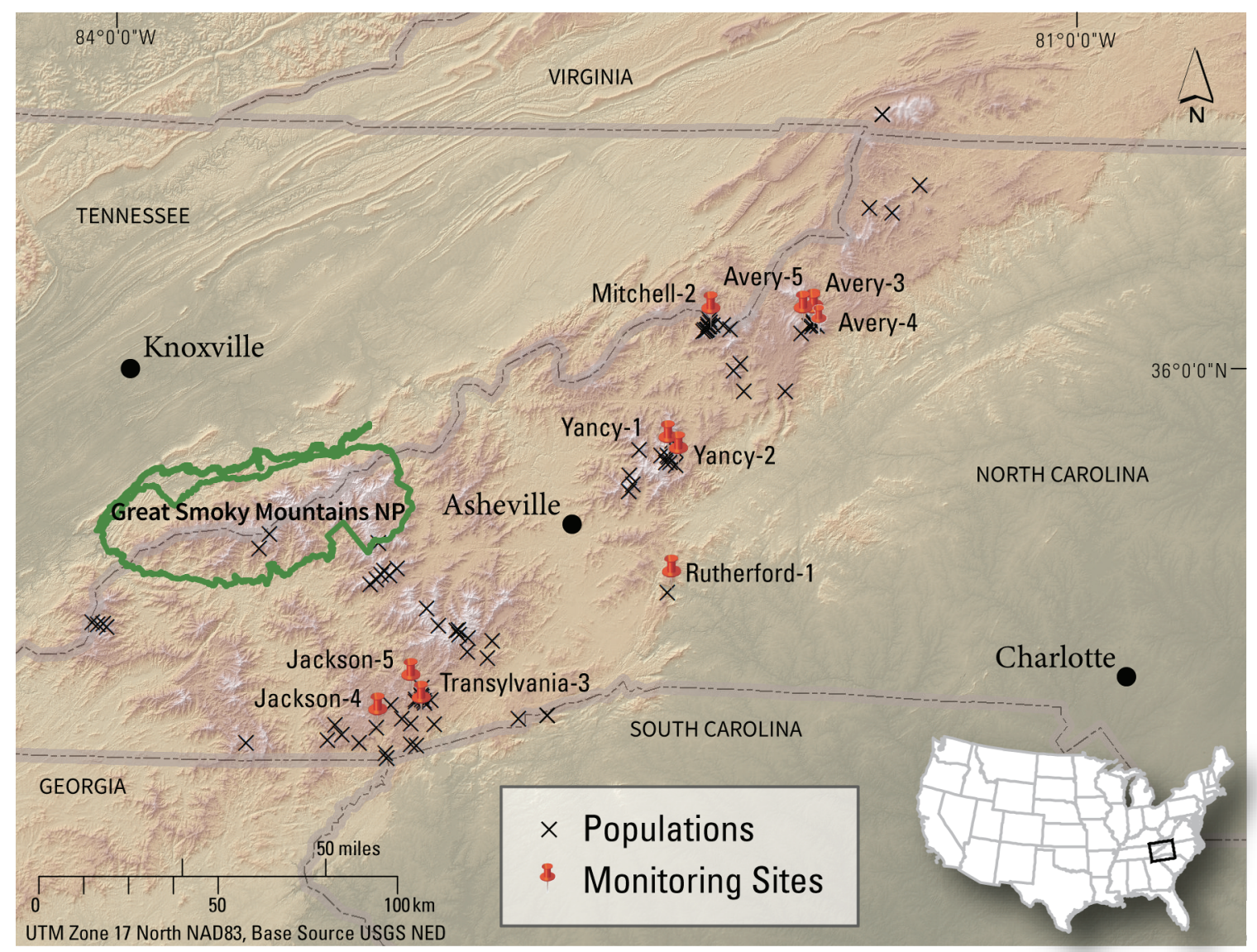

Figure 1. Distribution of known populations of Gymnoderma lineare and monitoring sites, southern Appalachian Mountains.

are not currently understood, changes in microclimate owing to the decline of adjacent high-elevation trees may result in excessive desiccation of the moist sites required by rock gnome lichen. Detrimental microclimate changes may be occurring at lower elevations owing to loss of eastern hemlock (Tsuga canadensis) and Carolina hemlock (Tsuga caroliniana) from riparian areas owing to another exotic insect, the hemlock woolly adelgid (Adelges tsugae; Vogt and others, 2016)

In addition to indirectly affecting rock gnome lichen habitat through declining tree cover, a wide variety of pollutants from precipitation (including sulfur dioxide, nitrate and ammonium) are known to accumulate in and damage lichens (St. Clair, 1987). Sulfur dioxide and other pollutants negatively affect physiological processes and membrane integrity, and cause thallus necrosis (Pearson and Rodgers, 1982; St. Clair, 1987). The critical load of deposition that results in damage to lichen communities is estimated at $4-8 \mathrm{~kg} / \mathrm{ha} / \mathrm{yr}$ for eastern temperate forests (Pardo and others, 2011). Heavy metals and ozone also have been reported to negatively affect the lichens' potassium efflux, chlorophyll content, and photosynthetic rates (Puckett, 1976; Nash and Sigal, 1979; Sigal and Taylor, 1979). Some species of lichens have been eliminated from the central Appalachian Mountains because of increasing levels of pollutants (Lawrey, 1987). Although no conclusive link was noted between rock gnome lichen condition and air pollution in a targeted study, populations with the lowest sulfur concentration were healthiest and vice versa; heavy metals did not exceed toxic levels (FWS, 2001). Unexplained declines in rock gnome lichen populations may be owing to air pollution (FWS, 2013).

The effects of climate change are thought to be more dramatic at high latitudes and elevations. Although the listing rule (FWS, 1995) and recovery plan (FWS, 1997) did not specifically identify climate change as a threat, climate change likely affects the high-elevation habitats where rock gnome lichen is found. Increases in average temperature or decreases in precipitation could render these sites unsuitable for the species. Incidence of cloud immersion also appears to be an important characteristic of these environments that could be affected by climate change (Berry and Smith, 2013). Observers have noticed periodic desiccation and (or) dieback of lichen thalli for this and other endemic lichens (FWS, 2013) that may be indicative of adverse effects of climate change (Allen and Lendemer, 2016). 
Despite the occurrence of rock gnome lichen primarily in protected areas, many of these areas nevertheless are subject to potentially deleterious recreational use such as hiking, rock climbing, and trampling near overlooks. Its habitat also is threatened by development of commercial and residential facilities and logging. Lichen collectors pose a threat to the species as well (FWS, 1997, 2013).

Genetic variability of rock gnome lichen has been shown to be owing to the genetic drift of geographically isolated populations (Allen and others, 2018) rather than to recombination among individuals. Because each population is genetically differentiated, loss of any population represents the loss of unique genetic diversity.

\section{Taxonomic Classification}

Rock gnome lichen is a squamulose lichen in the reindeer lichen family (Cladoniaceae). It was first described by Evans (1947) as Cladonia linearis based on material collected in Tennessee. It was later classified as Gymnoderma lineare by Yoshimura and Sharp (1968) owing to its short and solid podetia (stem-like structures supporting fruiting bodies) that lack symbiotic algae. Classified as such, it is the only member of this genus occurring in North America. Two other species of Gymnoderma occur in the mountains of Japan and Eastern Asia. More recently, the genus Gymnoderma Nyl. sensu Yoshimura and Sharp (Cladoniceae) has been reclassified as the genus Cetradonia in a new family Cetradoniaceae (Wei and Ahti, 2002). In the newly proposed classification, Gymnoderma lineare becomes Cetradonia linearis. Should this change be recognized in the Integrated Taxonomic Information System, the FWS will submit a technical change to the Federal list to change the scientific name of rock gnome lichen to Cetradonia linearis. This name change to a monotypic genus would increase the recovery priority from 5 to 4 .

\section{Current Endangered Species Act Status}

Rock gnome lichen was listed as endangered in 1995 (FWS, 1995), a recovery plan with down-listing criteria was completed in 1997 (FWS, 1997), and a 5-year review was published in 2013 (FWS, 2013). The next 5-year review was initiated in 2019. Criteria for down-listing from endangered to threatened under the Endangered Species Act according to the recovery plan (FWS, 1997) include (1) at least 30 populations that are stable over 5 years (not more than 10-percent cumulative loss in cover and no extirpation of other populations over 5 years), and (2) that these 30 populations must be in protective ownerships with continuous monitoring. De-listing criteria requirements are the same as those for down-listing but must include 40 stable populations over 10 years.

Rock gnome lichen has met down-listing and de-listing criteria regarding number of populations and the requirement for protective ownership. However, the agencies and individuals providing protected habitat generally have not monitored the populations. Data that have been collected from permanent plots by FWS in 1996-97 and 2008 have not been analyzed, partially owing to lack of comparability of repeat measurements at some plots. Data from a rapid-assessment protocol also are available to describe populations at points in time but sites have only been visited once.

\section{Objectives}

The FWS requested support from the U.S. Geological Survey (USGS) to develop a new monitoring protocol that will effectively determine trends of rock gnome lichen populations so that the final criterion for down-listing can be evaluated. As part of the project, a request was made to analyze previous monitoring efforts and data sources for detectable trends. This report documents the results of that effort.

\section{Methods}

Data holdings of the FWS regarding rock gnome lichen were provided by Rebekah Reid, Listing and Recovery Biologist, Asheville Field Office. The North Carolina Nature Heritage Program provided reports of locations and descriptions of occurrences of rock gnome lichen compiled by the North Carolina Natural Heritage Program (NCNHP), raw data and summarized data from the rapid assessment protocol and the standardized monitoring protocol (FWS, 1997), a summary of known populations compiled by FWS, and miscellaneous email communications and other reports regarding rock gnome lichen observations. The challenge was to discern trends in populations from this information.

\section{North Carolina Natural Heritage Program Reports}

The North Carolina Natural Heritage Program (NCNHP) compiles records of native plant observations in a central database. These records cover most of the rock gnome lichen populations but not the ones in South Carolina (1), Virginia (1), Tennessee (14), and Georgia (1). These States have their own Natural Heritage Programs but only South Carolina includes non-vascular plants in their list of threatened and endangered species. None of these programs were approached for information. The sites in Tennessee are all in Great Smoky Mountains National Park and detailed data are not available.

The NCNHP assigns an "element occurrence" (EO) number to each observation following the guidance of the Nature Conservancy (NatureServe, 2020). Geographically proximal sites are grouped under a "parent" EO and each parent EO is considered a population. With respect to rock gnome lichen, application of the Nature Conservancy standards for defining parent EOs results in sites that occur in the same watershed 
and are not separated by unsuitable habitat to be considered one population (FWS, 2013). Some observations in the NCNHP database are detailed and include estimates of population size but some simply document presence and (or) are not revisited. Few records are detailed enough to quantitatively describe population size and also have repeat observations.

\section{Rapid Assessment Protocol}

The rapid assessment protocol is meant to provide a quantitative snapshot of rock gnome lichen distribution and abundance across its range (FWS, 1997). It was not meant to be a monitoring protocol for detecting trends in sizes of populations. The protocol uses variably sized temporary plots to estimate cover in 10 cover classes $(<0.1,0.1-1,1-2,2-5$, $5-10,10-25,25-50,50-75,75-95$, and $95-100$ percent). The size of the plot is selected to minimize bare area. Condition of the lichen patch also is described as healthy, declining, or balding. The plot data are placed in the context of the entire population by estimating the percentage of the lichen patches that were sampled. Most sites with rapid assessment data were sampled in 2008 by Blue Ridge Parkway staff. Although this sampling was not intended for monitoring, perhaps the populations measured in 2008 could be re-evaluated to describe whether these populations are changing in size. Results for the various sites are summarized herein for easy comparison with new data, should it be collected.

\section{Monitoring Protocol}

A permanent plot-based monitoring protocol was published in the species recovery plan (FWS, 1997) to provide a standard methodology for use by all jurisdictions housing rock gnome lichen populations. The process included permanently marking the ends of a line transect and then holding $0.5-\times-0.5-\mathrm{m}$ quadrats against the transect at specific distances, both above and below, to create a 1-m-wide belt transect. The quadrats were gridded into 100 squares and each square was assigned a cover class; data were combined across squares to estimate total cover. General health of the population also was noted. Although the protocol was rigorous and should provide an accurate estimate of trends in cover, it also was onerous and repeat measurements were not always conducted using a layout consistent with the original data. Consequently, some plots were difficult to analyze and relatively few sites were monitored because of the time constraints. Sites also were not all measured in the same years. Nevertheless, results from the 10 sites with repeated measurements are presented herein as changes in absolute cover, changes in relative cover, and trends over appropriate time intervals.

\section{Environmental Data}

Among the potential threats to rock gnome lichen are environmental factors such as climate change and acid rain. Streamside populations also may be vulnerable to disturbance from high-flow events and desiccation from low flow. Trends in temperature and precipitation were described using the North Carolina Division 1 climate summary (National Oceanic and Atmospheric Administration, 2020). The trend in pollutants deposited in acid rain is summarized using total nitrogen and sulfate deposition using data from the National Atmospheric Deposition Program (NADP) site on Mount Mitchell (Site NC45; NADP, 2020) for years meeting full reporting criteria. Flow regime for the region is described using example data from USGS streamgage 03161000, South Fork New River near Jefferson, North Carolina (USGS, 2020). Trends in environmental drivers are compared qualitatively with trends in lichen cover.

\section{Results of Updated Analysis of Rock Gnome Populations}

The 5-year review of rock gnome lichen (FWS, 2013) indicated that there were 85 populations, which was an increase from 32 populations in 1995 (FWS, 1995). Subsequent re-evaluation of the sites by FWS staff and identification of new sites has led to a master list of 68 total populations distributed in North Carolina (61), Tennessee (6), South Carolina (1), Georgia (1), and Virginia (1) in 2019 (one population spans the North Carolina-Tennessee State line). This number exceeds the delisting criterion of 40 populations. Seven populations were newly discovered since 2012. Most of the known populations are on rocky outcrops (35); others are in or beside streams (20), have both habitats (11), or are unknown (2).

\section{NCNHP Records}

Four sites listed in the NCNHP database of EO records have records that include quantitative estimates of population size that were made in different years but were not formal monitoring or rapid assessment sites (table 1). The two sites with the earliest start dates and (or) were located adjacent to streams had negative trends. These time periods were associated with higher levels of acid rain than subsequently and a high-flow event in 1995 (fig. 2). 
Table 1. Rock gnome lichen (Gymnoderma lineare) monitoring sites with quantitative evidence of change found in North Carolina Natural Heritage Program records, southern Appalachian Mountains, 1987-2008.

[Each site was evaluated twice as indicated by the record interval. EO: Element occurrence. Type: OC, outcrop; S, stream. Owner: PRV, private; USFS, U.S. Forest Service. Symbols: $<$, less than; -, minus; +, plus]

\begin{tabular}{cllllclc}
\hline E0 & Location & Type & Owner & Record interval & $\begin{array}{c}\text { Initial cover } \\
\text { (square meters) }\end{array}$ & $\begin{array}{c}\text { Final cover } \\
\text { (square meters) }\end{array}$ & Trend \\
\hline 92.009 & Jackson-1 & S & USFS & $1987-2007$ & $<1$ & 0.14 & - \\
84.016 & Mitchell-1 & OC & USFS & $1983-96$ & $?$ & $<10$ percent of previous & - \\
21.000 & Ashe-1 & OC & PRV & $1989-97$ & 1 & 1.7 & + \\
51.000 & Macon-1 & OC & USFS & $1997-2008$ & 5 & At least 10 & + \\
\hline
\end{tabular}
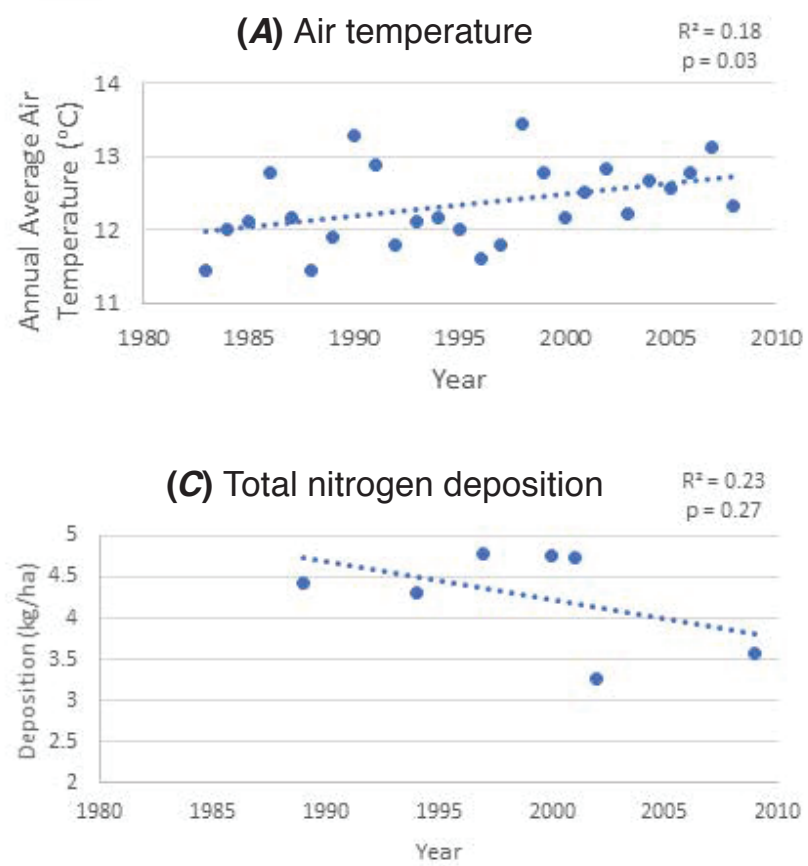

(E) Peak flow

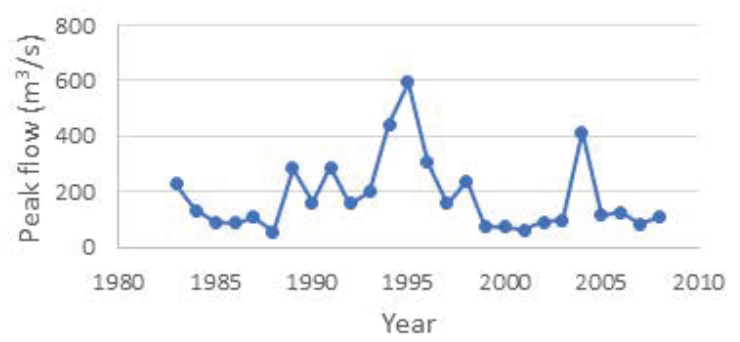

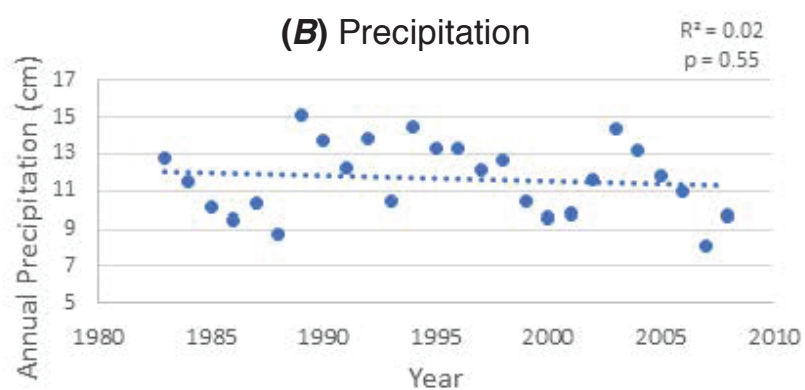

(D) Sulfate deposition $\quad R^{2}=0.55$

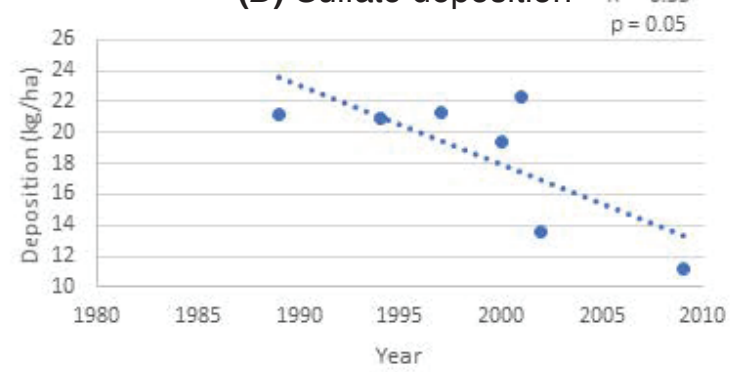

(F) Annual average discharge $R^{2}=0.05$

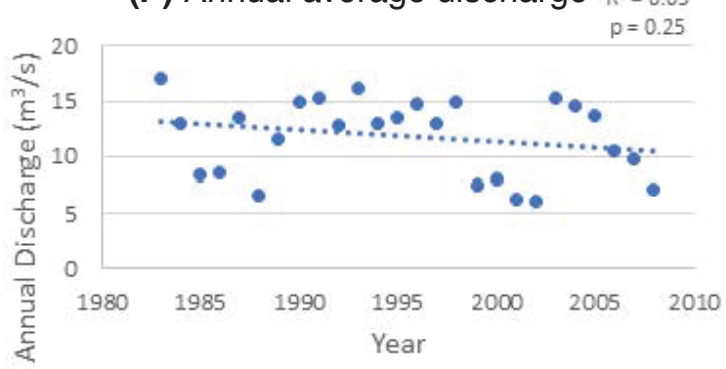

Figure 2. Trends in annual weather variables of $(A)$ air temperature and $(B)$ precipitation (North Carolina Division 1), acid (hydrogen ion) $(C)$ total nitrogen and (D) sulfate deposition (National Atmospheric Deposition Program site at Mount Mitchell, North Carolina), and $(E)$ peak flow and $(F)$ annual average discharge (U.S. Geological Survey streamgage 03161000, South Fork New River near Jefferson, North Carolina). $\mathrm{cm}$, centimeters; ${ }^{\circ} \mathrm{C}$, degrees Celsius; $\mathrm{m} 3 / \mathrm{s}$, cubic meters per second; $\mathrm{kg} / \mathrm{ha}$, kilograms per hectare; $\mathrm{p}$, probability that the null hypothesis is true; $\mathrm{R}^{2}$, Coefficient of determination. 


\section{Rapid Assessment Protocol}

The rapid assessment protocol was implemented at 20 sites mostly during 2008, all in North Carolina (table 2). Most sites were rocky outcrops but several were streamside sites. The data show that at least 16 sites had populations larger than $1 \mathrm{~m}^{2}$ and that 1 site had $0.68 \mathrm{~m}^{2}$ of cover in 2008. Cover was estimated at three other sites and it is probably safe to assume that populations were present although the data are missing. These sites are a sizable proportion of the 30 sites required for down-listing and 40 sites required for de-listing. Although the protocol was not intended to be used for monitoring, revisits to these sites and new estimates of cover may be useful to document stability of populations.

\section{Monitoring Protocol}

Permanent monitoring transects were established at 10 sites, with multiple transects at some sites. Sites were selected based on accessibility and available personnel to conduct the monitoring. The sites were distributed across most of the range of rock gnome lichen (fig. 1) but much of the data were collected at three sites in Avery County (Avery-3, Avery-4, Avery-5; table 3). All sites were located on rocky outcrops except Yancey-2, which was a streamside site. Sites were monitored over different time intervals so comparison among sites is challenging. Note also that initial cover area varied greatly $\left(94-12,844 \mathrm{~cm}^{2}\right)$.

When sites were grouped by time interval, the only interval with negative change was 1995-97 (table 4). Individual sites with loss of cover included Yancey-2 from 1996 to 2008. This was the only streamside site, possibly evidence of the peak flow event that occurred in 2004 in the region (fig. 2). The other negative trend was observed for two transects at Avery-5 from 1996 to 2001 . Notes on the data sheet indicate that a Fraser fir that had been providing shade had fallen, leaving the lichen with more sun exposure than before. The loss in cover was slight and the population recovered from 2001 to 2003. Comparison of relative change among time intervals where each time interval is initiated at zero (fig. 3) clearly showed a consistent positive trend from 1996 to 2008.

Table 2. Rock gnome lichen (Gymnoderma lineare) sites with rapid assessment protocol data collected in North Carolina in 2008.

[EO: Element occurrence. Type: OC, outcrop, S, stream. Owner: BLRI, Blue Ridge Parkway; MMSP, Mount Mitchell State Park GSMNP, Great Smoky Mountains National Park; USFS, U.S. Forest Service. Quadrat area: Sum of area for all variable-sized plots. Occupied area: Cover class midpoint multiplied by individual plot area, and summed. Total area: Percentage of site that was not sampled and added to occupied area]

\begin{tabular}{|c|c|c|c|c|c|c|}
\hline EO & Location & Type & Owner & $\begin{array}{c}\text { Quadrat area } \\
\text { (square meters) }\end{array}$ & $\begin{array}{c}\text { Occupied area } \\
\text { (square meters) }\end{array}$ & $\begin{array}{c}\text { Total area } \\
\text { (square meters) }\end{array}$ \\
\hline 4.000 & Swain-1 & $\mathrm{OC}$ & GSMNP & 0.36 & 0.31 & 1.94 \\
\hline 19.000 & Jackson-2 & $\mathrm{OC}$ & BLRI & 3.59 & 2.8 & 3.79 \\
\hline 20.000 & Transylvania-2 & $\mathrm{OC}$ & BLRI & 13.67 & 10.37 & 14.52 \\
\hline 72.042 & Buncombe-2 & $\mathrm{OC}$ & BLRI & 2.22 & 1.43 & 1.43 \\
\hline 72.069 & Buncombe-3 & $\mathrm{OC}$ & BLRI & 7.81 & 3.05 & 3.32 \\
\hline 72.070 & Buncombe-4 & $\mathrm{OC}$ & BLRI & 10.3 & 4.28 & 5.99 \\
\hline 72.071 & Buncombe-5 & $\mathrm{OC}$ & BLRI & 11.47 & 7.64 & 11.47 \\
\hline 83.035 & Avery-2 & $\mathrm{OC}$ & BLRI & 2.1 & 0.81 & 0.83 \\
\hline 85.015 & Yancey-1 & $\mathrm{OC}$ & MMSP & 3.65 & 2.39 & 2.63 \\
\hline 86.045 & Haywood-1 & $\mathrm{OC}$ & USFS & 4.38 & 1.60 & 1.93 \\
\hline 87.024 & Jackson-3 & $\mathrm{OC}$ & BLRI & 1.85 & 1.34 & 1.47 \\
\hline
\end{tabular}




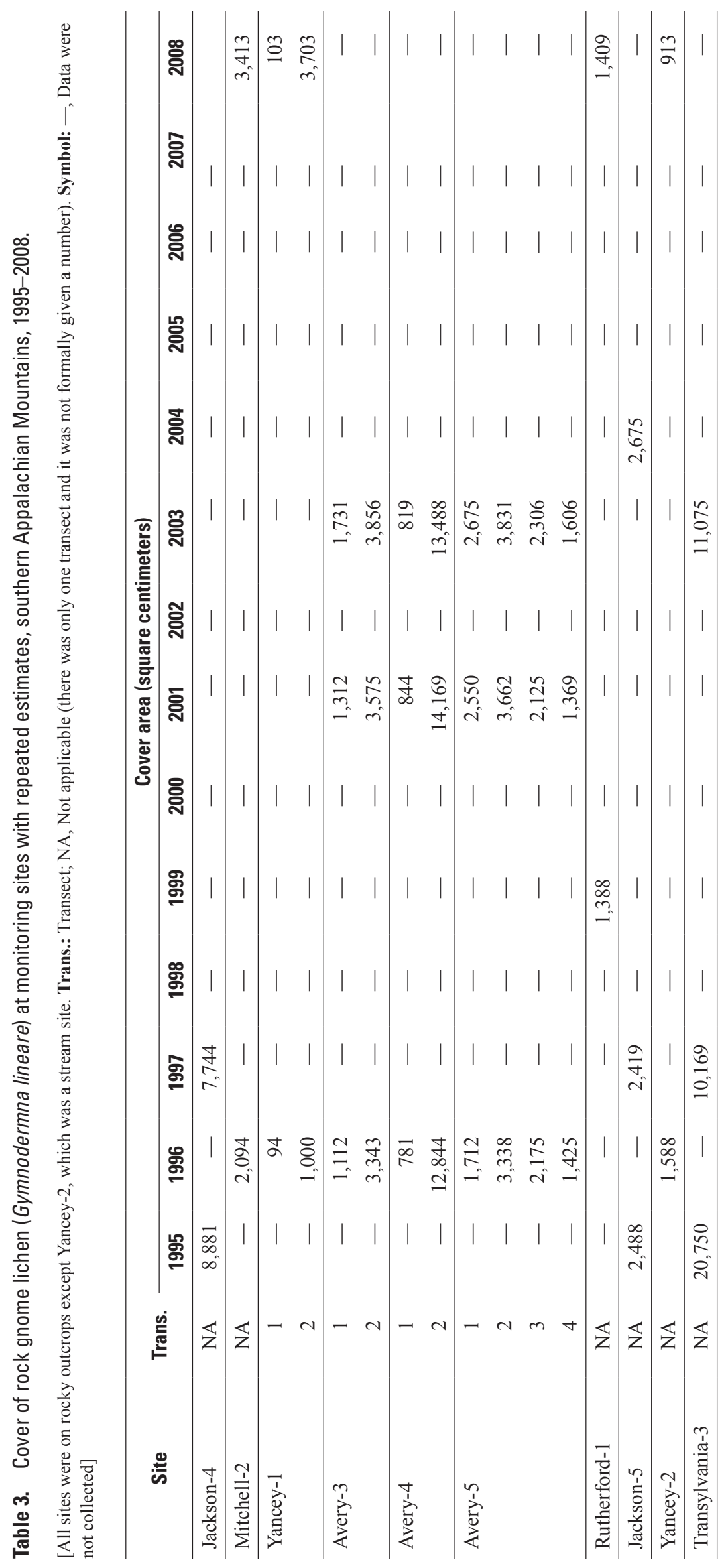


Table 4. Summary of monitoring results by time interval for rock gnome lichen (Gymnoderma lineare), southern Appalachian Aoburgtaómse 1895e-2060\%mnoderma lineare), southern Appalachian

Mountains, 1995-2008.

[Trans.: Transect; NA, Not applicable (there was only one transect and it was not formally given a number). Symbol: -, Data were not collected]

\begin{tabular}{|c|c|c|c|c|c|}
\hline $\begin{array}{c}\text { Time } \\
\text { interval }\end{array}$ & Site & Trans. & $\begin{array}{c}\text { Change } \\
\text { (proportion) }\end{array}$ & $\begin{array}{c}\text { Site } \\
\text { (mean) }\end{array}$ & $\begin{array}{c}\text { All } \\
\text { sites } \\
\text { mean) }\end{array}$ \\
\hline \multirow{3}{*}{$\begin{array}{l}1995- \\
97\end{array}$} & Jackson-4 & NA & -0.13 & -0.13 & -0.22 \\
\hline & Jackson-5 & NA & -0.03 & -0.03 & - \\
\hline & Transylvania-3 & NA & -0.51 & -0.51 & - \\
\hline \multirow{8}{*}{$\begin{array}{l}1996- \\
2001\end{array}$} & Avery-3 & 1 & 0.18 & 0.12 & 0.12 \\
\hline & & 2 & 0.07 & - & - \\
\hline & Avery-4 & 1 & 0.08 & 0.09 & - \\
\hline & & 2 & 0.1 & - & - \\
\hline & Avery-5 & 1 & 0.49 & 0.13 & - \\
\hline & & 2 & 0.1 & - & - \\
\hline & & 3 & -0.02 & - & - \\
\hline & & 4 & -0.04 & - & - \\
\hline \multirow{8}{*}{$\begin{array}{l}1996- \\
2003\end{array}$} & Avery-3 & 1 & 0.56 & 0.35 & 0.21 \\
\hline & & 2 & 0.15 & - & - \\
\hline & Avery-4 & 1 & 0.05 & 0.05 & - \\
\hline & & 2 & 0.05 & - & - \\
\hline & Avery-5 & 1 & 0.56 & 0.22 & - \\
\hline & & 2 & 0.15 & - & - \\
\hline & & 3 & 0.06 & - & - \\
\hline & & 4 & 0.13 & - & - \\
\hline
\end{tabular}

\begin{tabular}{llcccc}
\hline \multirow{2}{*}{$\begin{array}{c}\text { Time } \\
\text { interval }\end{array}$} & Site & Trans. & $\begin{array}{c}\text { Change } \\
\text { (proportion) }\end{array}$ & $\begin{array}{c}\text { Site } \\
\text { (mean) }\end{array}$ & $\begin{array}{c}\text { All } \\
\text { sites } \\
\text { mean) }\end{array}$ \\
\hline $1996-$ & Mitchell-2 & NA & 0.63 & 0.63 & 0.53 \\
\cline { 2 - 6 } 2008 & Yancey-1 & 1 & 0.1 & 1.4 & - \\
& Yancey-2 & NA & -0.43 & -0.43 & - \\
\hline $2001-$ & Avery-3 & 1 & 0.32 & 0.2 & 0.08 \\
03 & & 2 & 0.08 & - & - \\
\cline { 2 - 6 } & Avery-4 & 1 & -0.03 & -0.04 & - \\
\cline { 2 - 6 } & & 2 & -0.05 & - & - \\
\hline & Avery-5 & 1 & $0 / 05$ & 0.09 & - \\
& & 2 & 0.05 & - & - \\
& & 3 & 0.09 & - & - \\
\hline
\end{tabular}

\section{Environmental Data}

Changes in environmental conditions are among the threats to rock gnome lichen. Regional climate data show a significant increase in temperature $(p=0.03)$ and a nonsignificant change in precipitation $(\mathrm{p}=0.55)$ over the period of lichen monitoring (fig. 2). Deposition of total nitrogen $(p=0.27)$ and sulfate $(p=0.05)$ from precipitation showed decreasing trends, especially in the later part of the period, although only sulfate was significant. Streamside lichen

communities usually occur on boulders in or adjacent to rivers and streams and are vulnerable to high-flow events. An example streamflow record from Ashe County, North Carolina, shows that extreme-flow events occurred in 1995 and 2004. There also have been anecdotal reports that some streamside populations have appeared desiccated, perhaps owing to low streamflow (FWS, 2013). Streamgage data show no significant trend in the annual average of daily discharge $(p=0.25)$ from 1983 to 2008. 


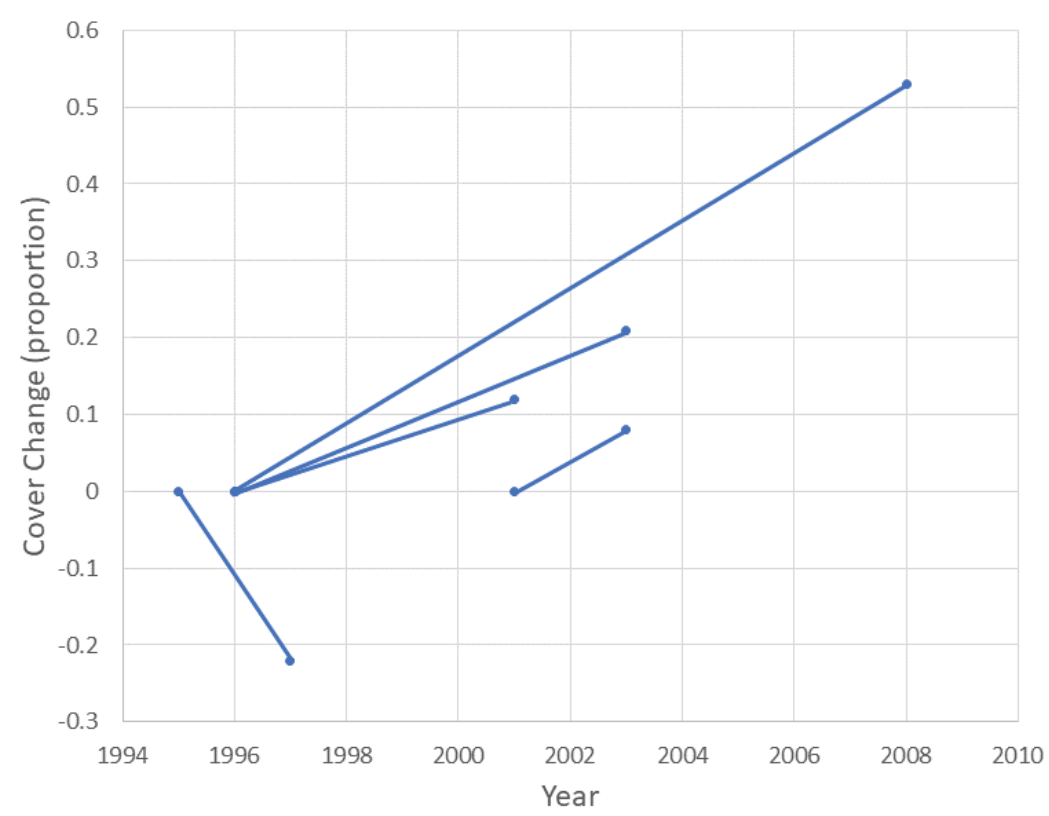

Figure 3. Trends in cover of rock gnome lichen (Gymnoderma lineare) determined over several monitoring time intervals, southern Appalachian Mountains. See table 4 for sites included in lines showing each time interval.

\section{Discussion}

\section{Trends}

The number of reported rock gnome lichen populations has increased and the sizes of populations seem to have enlarged since the species was listed in 1995 (FWS, 1995) until 2008. Even with consolidation of some populations counted in 2013 (FWS, 2013) after refinement of the population definition, the total number of populations exceeded the 40 required for down-listing in 2019. Seven new populations have been located since 2012, perhaps indicating that there are more to be discovered.

Prior to development of the recovery plan (FWS, 1997), there were anecdotal reports that several populations of rock gnome lichen had had significant declines, including in an unpublished report from Bluff Mountain Preserve describing the period from 1989 to 1993 (Heiman and Bucher, 1995; FWS, 1997). Results from permanent plot monitoring reported herein also indicate population decline from 1995 to 1997 whereas monitoring in subsequent intervals showed steadily increasing populations. Although much of the data come from a small geographic area in Avery County, the results are consistent across all nine sites monitored since 1997, which span much of the known range of rock gnome lichen. In the two cases where trend results were negative, the results can be explained by local events. In one case, a Fraser fir fell and exposed the population to increased solar radiation (Avery-4, 2001-03); in the other case, the only streamside population in the dataset was vulnerable to a high-flow event in 2004 (Yancey-2, 1996-2008). In total, these results indicate that growing conditions for rock gnome lichen were favorable during 1996-2008 and that the causes of decline are natural events rather than direct anthropogenic damage.

\section{Environmental Drivers}

The observation that populations of rock gnome lichen seem to be growing is a sign that recreational activities and lichen collecting may not have been widespread threats to the species during 1996-2008, likely due to restrictions on recreational rock climbing and collecting previously put in place. Moreover, examination of potential environmental drivers of population change (fig. 2) suggest that a decrease in sulfate and nitrogen ion deposition from acid rain may mean that growing conditions improved for rock gnome lichen over the period when monitoring data are available. At the same time, a significant but highly variable increase in annual temperature occurred. Although this trend eventually may have negative consequences for rock gnome lichen, effects were not apparent from 1996 to 2008. Instead, the peak flow event in 2004 may have threatened streamside populations. 


\section{Future of Threats}

Anthropogenic climate change poses general challenges for ecosystems. Climate change projections for the southeastern region of the United States include an increase in annual air temperature of $1.5-3.0^{\circ} \mathrm{C}$, an increase in growing season length, an increase in variability of precipitation, and an increase in the frequency of extreme precipitation events, both wet and droughty conditions (Ingram and others, 2013; Mitchell and others, 2014). Because effects are expected to be most dramatic at high elevations, endemic species occupying these areas are at disproportionate risk of extinction (Dirnböck and others, 2011). In a study of the habitat of Geum radiatum Michx., a federally listed endangered species that inhabits sites similar to those of rock gnome lichen, Ulrey and others (2016) reported that these Pleistocene refugia are extremely vulnerable to climate change. Warmer, drier conditions likely will reduce relative humidity and make them unsuitable for the endemic flora that they currently protect. Moreover, these species cannot easily migrate to other areas because they grow on isolated mountaintops. The potential for more powerful and frequent high-flow events or desiccation due to sustained low streamflow also poses greater threats to streamside populations, which grow on boulders in or adjacent to flowing water (Allen, 2017).

Deposition of pollutants from the atmosphere has been a threat to terrestrial and aquatic organisms for decades. Peak deposition occurred in 1973 and declined 67 percent by 2009 owing to reduction in emissions required by the Clean Air Act (Burns and others, 2011). A time lag is predicted for recovery of ecosystem processes, however (Gilliam and others, 2019). Nevertheless, rock gnome lichen is thought to be sensitive to airborne contaminants (Martin and Noble, 1996; Southern Appalachian Man and the Biosphere Program, 1996) and reduction in acid rain deposition seems to be associated with growth of rock gnome lichen populations. By the end of the study period, total nitrogen ion deposition was less than the critical load estimated for lichens growing in Eastern United States temperate forests (Pardo and others, 2011).

Spruce-fir forests surround rocky outcrops occupied by rock gnome lichen and provide shade and other microclimatic benefits. Fraser fir, in particular, has been adversely affected by several stressors in recent decades, including acid rain, climate change and balsam woolly adelgid parasitism resulting in 91-percent mortality since 1950 in some parts of Great Smoky Mountains National Park (Dull and others, 1988). Using monitoring data collected since 1980 and modeling techniques, Kaylor and others (2017) forecasted the future of Fraser fir populations. They concluded that if current levels of stressors persist, high-elevation populations will have robust recovery for at least several decades while the low-elevation population on Mount Sterling will decline. However, substantial changes in balsam woolly adelgid outbreak dynamics and (or) climate change may endanger high-elevation populations. The threat posed to rock gnome lichen by loss of Fraser fir in surrounding forests owing to pests and direct effects of climate change is likely to lessen for the near future. However, the indirect effect of climate on fire regime may dramatically alter forest structure as exemplified by the fires that burned $72 \mathrm{~km}^{2}$ in the Great Smoky Mountains in 2016. Although those fires likely were caused by arson and power lines, fire behavior was accelerated by weather conditions (Charney and others, 2019).

Eastern hemlock and Carolina hemlock also are under attack by an exotic insect, hemlock woolly adelgid. The adelgid was first seen in North Carolina in 1995 and had infested the entire range of hemlocks in North Carolina by 2008 (Vogt and others, 2016). Analysis of data from 1999 to 2013 showed a 50-percent decrease in survival and a 50-percent reduction in growth for remaining hemlocks. These changes could affect the microclimate in riparian areas and be detrimental to streamside rock gnome lichen populations.

Recreational effects may have been minor during 2008 but increasing use of these areas owing to growth of urban areas means that the threat may be renewed. Great Smoky Mountains National Park was the third most visited national park unit in 2019, with more than 12.5 million guests and visitation increasing by more than 1 million over 2018 (NPS, 2020).

\section{Future Work}

An effective, easily implemented monitoring protocol is the most pressing need for protecting rock gnome lichen. Besides addressing the listing criteria, a monitoring protocol would provide greater understanding of lichen growth dynamics in relation to environmental conditions, especially if implemented frequently in at least a few locations. Additionally, the increase in populations noted since 2012 (after the number in the 5-year review [FWS, 2013] was validated) suggests that there may be more such population increases. Use of habitat models could help identify new sites and one such model is under development for Great Smoky Mountains National Park. Knowledge of additional populations would provide confidence that it is safe to reduce the protected status of rock gnome lichen. It would also help establish whether the full habitat range of the species is understood. Research has shown that much of the genetic variation in this species is due to genetic drift within geographically isolated populations (Allen and others, 2018); therefore, loss or discovery of any population is important for conservation of the species. Many other research needs are identified in the recovery plan (FWS, 1997).

The rapid assessment protocol was not designed to be used for monitoring. Nevertheless, if the data are at all repeatable, they could provide an assessment of population conditions from 2008 to present. These 20 sites would be a significant part of the 30 populations requiring documented stability for down-listing. Perhaps some of the permanent plots also could be revisited, although most permanent markings are thought to be lost in the intervening 12 years since they were last measured. 


\section{Conclusions}

After seeming to be in decline during the 1980 s and 1990s, growth conditions for rock gnome lichen (Gymnoderma lineare [Evans]) appear to have improved from 1996 to 2008 in the southern Appalachian Mountains. This may be due to the lessening of effects from both acid rain and loss of Fraser fir (Abies fraseri) plus increased protection from recreational activities and collecting during that period. More populations have been found and perhaps more exist. As some threats become less potent, the threat of changing climate is increasing. Rock gnome lichen and other southern Appalachian endemics live in refugial habitats that are cooler and wetter than the ambient climate. Climate change likely will impair the ability of these sites to provide suitable habitat for a suite of endemic species. The rate of change and strength of consequences remain to be seen.

\section{Acknowledgments}

I owe many thanks to Rebekah Reid (U.S. Fish and Wildlife Service) for introducing me to the rock gnome lichen in its habitat and providing data and much discussion. Jessica Allen (Eastern Washington University), Martin Hutten (Glacier Bay National Park and Preserve), and Rebekah Reid improved this report with their comments.

\section{References Cited}

Allen, J., 2017, Lichen conservation in eastern North America-Population genomics, climate change, and translocations: New York, City University of New York, Ph.D. dissertation, 135 p. [Also available at https://academicworks.cuny.edu/gc_etds/2059.]

Allen, J.L., and Lendemer, J.C., 2016, Climate change impacts on endemic, high-elevation lichens in a biodiversity hotspot: Biodiversity and Conservation, v. 25, no. 3, p. 555-568.

Allen, J.L., McKenzie, S.K., Sleith, R.S., and Alter, S.E., 2018, First genome-wide analysis of the endangered, endemic lichen Cetradonia linearis reveals isolation by distance and strong population structure: American Journal of Botany, v. 105, no. 9, p. 1556-1567.

Berry, Z.C., and Smith, W.K., 2013, Ecophysiological importance of cloud immersion in a relic spruce-fir forest at elevation limits, southern Appalachian Mountains, USA: Oecologia, v. 173, no. 3, p. 637-648. https://doi.org/ 10.1007/s00442-013-2653-4.
Burns, D.A., Lynch, J.A., Cosby, B.J., Fenn, M.E., and Baron, J.S., 2011, National acid precipitation assessment program report to Congress 2011 - An integrated assessment: Washington, D.C., National Science and Technology Council, 114 p.

Charney, J.J., Shadbolt, R.P., and Fromm, H., 2019, A mesoscale simulation of mountain wave event associated with the Chimney Tops 2 Fire (2016) [abs.] - American Meteorological Society 99th Annual Meeting, Phoenix, Arizona, January 6-10, 2019, Abstract 384.

Dirnböck, T., Essl, F., and Rabitsch, W., 2011, Disproportional risk for habitat loss of high-altitude endemic species under climate change: Global Change Biology, v. 17, no. 2, p. $990-996$.

Dull, C.W., Ward, J.D., Brown, H.D., Ryan, G.W., Clerke, W.H., and Uhler, R.J., 1988, Evaluation of spruce and fir mortality in the southern Appalachian Mountains: U.S. Forest Service, Southern Region, Atlanta, Georgia, Report Number R8-PR 13.92 p.

Estill, J.C., and Cruzen, M.B., 2001, Phytogeography of rare plant species endemic to the Southeastern United States: Castanea, v. 66, p. 3-23.

Evans, A.W., 1947, A study of certain North American Cladoniae: The Bryologist, v. 50, no. 1, p. 14-51.

Gilliam, F.S., Burns, D.A., Driscoll, C.T., Frey, S.D., Lovett, G.M., and Watmough, S.A., 2019, Decreased atmospheric nitrogen deposition in eastern North America-Predicted responses of forest ecosystems: Environmental Pollution, v. 244 , p. $560-574$.

Heiman, K.A., and Bucher, M.A., 1995, Lichen monitoring on a mountain preserve: Unpublished report, U.S. Fish and Wildlife Service, Asheville, North Carolina.

Ingram, K., Dow, K., Carter, L., and Anderson, J., eds., 2013, Climate change of the Southeast United States_-Variability, change, impacts, and vulnerability: Washington, D.C., Island Press.

Kaylor, D.S., Hughes, M.J., and Franklin, J.A., 2017, Recovery trends and predictions of Fraser fir (Abies fraseri) dynamics in the southern Appalachian Mountains: Canadian Journal of Forest Research, v. 47, no. 1, p. 125-133.

Lawrey, J.D., 1987, Lichens as indicators of atmospheric quality in the northern district of Shenandoah National Park, Virginia: Final report to the U. S. National Park Service, Denver, Colorado.

Loehle, C., 2007, Predicting Pleistocene climate from vegetation in North America: Climate of the Past, v. 3, no. 1, p. 109-118. 
Martin, J., and Noble, R.D., 1996, A quantitative study on ecological status and trends in an endangered lichen, Gymnoderma lineare (Evans) Yoshimura and Sharp-Final report: Prepared for U.S. Forest Service, National Forests in North Carolina, Asheville, North Carolina, and U.S. Fish and Wildlife Service, Asheville, North Carolina, $30 \mathrm{p}$.

Mitchell, R.J., Liu, Y., O’Brien, J.J., Elliott, K.J., Starr, G., Miniat, C.F., and Hiers, J.K., 2014, Future climate and fire interactions in the southeastern region of the United States: Forest Ecology and Management, v. 327, p. 316-326.

Nash, T.H., III, and Sigal, L.L., 1979, Gross photosynthetic response of lichens to short-term ozone fumigations: The Bryologist, v. 82, no. 2, p. 280-285.

National Atmospheric Deposition Program [NADP], 2020, NADP Maps and data: NADP web page, accessed June 19, 2020, at http://nadp.slh.wisc.edu/data.

National Oceanic and Atmospheric Administration, 2020, Climate at a glance: National Oceanic and Atmospheric Administration web page, accessed June 17, 2020, at https://www.ncdc.noaa.gov/cag/divisional/mapping.

National Park Service [NPS], 2020, Visitation numbers: NPS web page, accessed June 29, 2020, at https://www.nps.gov/ aboutus/visitation-numbers.htm.

NatureServe, 2020, Our mission: NatureServe web page accessed, June 19, 2020, at https:/www.natureserve.org.

Pardo, L.H., Fenn, M.E., Goodale, C.L., Geiser, L.H., Driscoll, C.T., Allen, E.B., Baron, J.S., Bobbink, R., Bowman, W.D., Clark, C.M., Emmett, B., Gilliam, F.S., Greaver, T.L., Hall, S.J., Lilleskov, E.A., Liu, L., Lynch, J.A., Nadelhoffer, K.J., Perakis, S.S., Robin-Abbott, M.J., Stoddard, J.L., Weathers, K.C., and Dennis, R.L., 2011, Effects of nitrogen deposition and empirical nitrogen critical loads for ecoregions of the United States: Ecological Applications, v. 21, no. 8, p. 3049-3082.

Pearson, L., and Rodgers, G., 1982, Air pollution damage to cell membrane in lichens-III-Field experiments: Phyton, v. 22 , p. $329-337$.

Puckett, K., 1976, The effects of heavy metals on some aspects of lichen physiology: Canadian Journal of Botany, v. 54, no. 23, p. 2695-2703, https://doi.org/10.1139/b76-290.

Russell, D.A., Rich, F.J., Schneider, V., and Lynch-Stieglitz, J., 2009, A warm thermal enclave in the Late Pleistocene of the South-eastern United States: Biological Reviews of the Cambridge Philosophical Society, v. 84, no. 2, p. 173-202.

Sigal, L.L., and Taylor, O.C., 1979, Preliminary studies on the gross photosynthetic response of lichens to peroxyacetylnitrate fumigations: The Bryologist, v. 82, no. 4, p. 564-575.
Southern Appalachian Man and the Biosphere Program, 1996, The southern Appalachian assessment summary report R8-TP 25, report 1 of 5: U.S. Forest Service, Southern Region, Atlanta, Georgia, 118 p.

St. Clair, L., 1987, Final report concerning the establishment of an air quality biomonitoring program using various lichen parameters in the James River Face Wilderness Area, Jefferson National Forest, Virginia-U.S. Forest Service: Roanoke, Virginia, Jefferson National Forest, 16 p.

Ulrey, C., Quintana-Ascencio, P.F., Kauffman, G., Smith, A.B., and Menges, E.S., 2016, Life at the top-Longterm demography, microclimatic refugia, and responses to climate change for a high-elevation southern Appalachian endemic plant: Biological Conservation, v. 200, p. 80-92.

U.S. Fish and Wildlife Service [FWS], 1995, Endangered and threatened wildlife and plant; determination of Gymnoderma lineare (rock gnome lichen) to be and endangered species: Federal Register, v. 60, p. 3557-3562.

U.S. Fish and Wildlife Service [FWS], 1997, Recovery plan for the rock gnome lichen (Gymnoderma lineare) (Evans) Yoshimura and Sharp: U. S. Fish and Wildlife Service, Southeast Region, Atlanta, Georgia, 30 p.

U.S. Fish and Wildlife Service [FWS], 2001, Endangered and threatened wildlife and plants; Determination that designation of critical habitat is not prudent for the rock gnome lichen: Federal Register, v. 66, p. 51445-51552.

U.S. Fish and Wildlife Service [FWS], 2013, Rock gnome lichen (Gymnoderma lineare) 5-year review-Summary and evaluation: U.S. Fish and Wildlife Service, Southeast Region, Asheville Ecological Service Field Office, Asheville, North Carolina, $16 \mathrm{p}$.

U.S. Geological Survey [USGS], 2020, USGS National Water Information System: USGS web page, accessed June 19, 2020, at https://waterdata.usgs.gov/usa/nwis/uv?site_ no03161000.

Vogt, J.T., Roesch, F.A., and Brown, M.J., 2016, Hemlock woolly adepgid (Adelges tsugae) and hemlock (Tsuga spp.) in western North Carolina-What do forest inventory and analysis tell us?: Southeastern Naturalist, v. 15, no. 4, p. 631-645.

Wei, J., and Ahti, T., 2002, Cetradonia, a new genus in the new family Cetradoniaceae (Lecanorales, Ascomycota): Lichenologist, v. 34, no. 1, p. 19-31.

Yoshimura, I., and Sharp, A.J., 1968, A revision of the genus Gymnoderma: American Journal of Botany, v. 55, no. 5, p. 635-640. https://doi.org/10.1002/j.15372197.1968.tb07422.x. 
Publishing support provided by the U.S. Geological Survey Science Publishing Network, Tacoma Publishing Service Center

For more information concerning the research in this report, contact the Director, Forest and Rangeland Ecosystem Science Center U.S. Geological Survey

777 NW 9th St., Suite 400

Corvallis, Oregon 97330

https:///www.usgs.gov/centers/fresc/ 


\section{एँ}

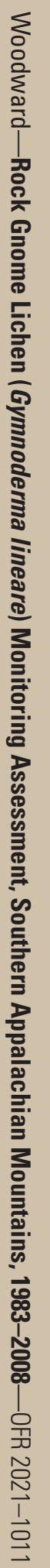

